\title{
NOTE
}

\section{Disease and mortality among Yesso scallops Patinopecten yessoensis putatively caused by infection with Francisella halioticida}

\author{
Gary R. Meyer*, Geoffrey J. Lowe, Scott R. Gilmore, Susan M. Bower \\ Fisheries and Oceans Canada, Pacific Biological Station, Nanaimo, BC V9T 6N7, Canada
}

\begin{abstract}
During the fall of 2015, up to $40 \%$ mortality occurred in juvenile Yesso scallops Patinopecten yessoensis at an aquaculture site in Baynes Sound, British Columbia, Canada. Macroscopic lesions were present in $11 \%$ of the scallops, and histopathology consisting of multifocal and diffuse haemocyte infiltration was observed in $44 \%$ of the specimens examined. Histologically, small Gram-negative intracellular bacteria-like particles were observed within necrotic haemocytes of the lesions, suggesting a bacterial aetiology. DNA was extracted from adductor muscle lesions of diseased scallops, and the 16s rDNA gene as well as the DNA-directed RNA polymerase beta subunit $(r p o B)$ were amplified by PCR. Sequence analyses of the resulting 413 and $925 \mathrm{bp}$ fragments were a $100 \%$ match to the reference sequence for Francisella halioticida, originally described as the cause of mortality in abalone from Japan. Isolation and culture of the bacteria was not possible at the time, as no further diseased specimens were available. Results from in situ hybridization assays as well as examination by transmission electron microscopy provide further evidence supporting the hypothesis that $F$. halioticida was the most probable causative agent of the lesions and mortality.
\end{abstract}

KEY WORDS: Scallop $\cdot$ Lesions $\cdot$ Histopathology $\cdot$ Bacteria

\section{INTRODUCTION}

During the fall of 2015 , up to $40 \%$ mortality was reported among juvenile Yesso scallops Patinopecten yessoensis following approximately 6 mo of suspended culture in Baynes Sound, British Columbia (BC), Canada. The scallop seed originated from a nearby land-based hatchery and were outplanted to the marine environment when they were about 3 mo old. Necropsy and gross examination revealed that $11 \%(7 / 65)$ of the scallops had small (1 to $3 \mathrm{~mm}$ diameter) pinkish pustules and/or diffuse coalescing areas of pus within the adductor muscle, and the digestive gland was often pale in colour. In addition,

${ }^{*}$ Corresponding author: gary.meyer@dfo-mpo.gc.ca approximately $50 \%$ of the specimens showed varying levels of shell damage consisting of erosion or chips along the leading edge which were often associated with conchiolin deposits and believed to be the result of mechanical abrasion or 'biting' damage from other scallops. Similar observations of pustules in the connective tissue of all organs and shell damage were reported in cultured scallops from BC during the late 1980s and 1990s (for images see www. dfo-mpo.gc.ca/science/aah-saa/diseases-maladies/ ibdsc-eng.html). Studies at that time concluded that the lesions were most likely caused by a cryptic infectious agent such as an intracellular bacterium or possibly a virus. It was also hypothesized that this

(C) Fisheries and Oceans Canada 2017. Open Access under Creative Commons by Attribution Licence. Use, distribution and reproduction are unrestricted. Authors and original publication must be credited. 
could be a chronic disease condition associated with stress (Bower et al. 1992, Bower \& Meyer 1994, Getchell et al. 2016).

The findings from our study indicate that the intracellular bacterium Francisella halioticida is the most probable aetiological agent for the lesions. Bacteria in the genus Francisella are Gram-negative, nonmotile, facultative intracellular, non-spore forming cocco-bacilli (Eigelsbach \& McGann 1984, Sjöstedt 2005, Jones \& Smith 2014). It is noteworthy that the bacteria in this genus are considered to be highly virulent and cause serious disease in a wide range of hosts; infections are often referred to as francisellosis. For example, F. tularensis causes a highly contagious and serious disease of mammals (Oyston 2008) and F. noatuensis can cause a severe systemic granulomatous inflammatory disease in fish (Nylund et al. 2006, Jones \& Smith 2014). Similarly, F. halioticida is also known to be pathogenic and was originally described as the cause of mass mortality among farmed abalone Haliotis gigantea in Japan (Kamaishi et al. 2010, Brevik et al. 2011).

\section{MATERIALS AND METHODS}

\section{Sample collection}

On 2 occasions during 2015, juvenile Patinopecten yessoensis $(\mathrm{n}=65)$ were collected from an aquaculture site in Baynes Sound, BC, for disease examination. Initial samples were collected on 30 November ( $\mathrm{n}=24$ ) with additional samples collected on 14 December $(\mathrm{n}=41)$. All scallops were approximately 9 mo old, and the shell height measurements ranged from 18 to $44 \mathrm{~mm}$. For each scallop, the adductor muscle attachment site was severed along the right valve, the shell was removed, and tissues were examined macroscopically for lesions and abnormalities.

\section{Histology}

Tissue samples were preserved in Davidson's solution (Howard et al. 2004) and processed using routine histology techniques for paraffin embedding. Five $\mu \mathrm{m}$ thick tissue sections were deparaffinized and stained with Harris' modified haematoxylin and eosin (H\&E); in addition, a subset of tissue sections with lesions were stained using Gram stain. Histology slides were examined and photographed via light microscopy (100 to $1000 \times$ magnification).

\section{Transmission electron microscopy (TEM)}

Visible lesions in the adductor muscle were excised and cut into small pieces ( 2 to $3 \mathrm{~mm}$ cubes), preserved in $2.5 \%$ gluteraldehyde in $0.1 \mathrm{M}$ cacodylate buffer (pH 7.2) overnight at $4^{\circ} \mathrm{C}$. Tissues were rinsed 3 times with the same buffer, post fixed for $1.5 \mathrm{~h}$ in $1 \%$ osmium tetroxide, rinsed another 3 times with buffer, dehydrated through an ethanol series and acetone followed by infiltration and embedding in epoxy resin (Eponate $12 \mathrm{kit}$, Marivac). Thin sections (70-80 nm) were mounted on grids, stained with uranyl acetate and Sato's modified triple lead citrate and examined using a Jeol JEM-1011 transmission electron microscope outfitted with a Gatan Erlangshen CCD camera.

\section{Polymerase chain reaction (PCR) and sequencing}

Small pieces of adductor muscle containing lesions from 3 scallops were preserved in $95 \%$ ethanol, and DNA extraction was performed using a DNEasy tissue Kit (Qiagen) according to the manufacturer's instructions. The extracted DNA concentration and purity were measured using a Nanodrop spectrophotometer. PCR assays were conducted using previously published primer pairs designed to amplify bacterial 16S ribosomal DNA (rDNA) (primers 968f and 1401r; Nübel et al. 1996), as well as the DNA-directed RNA polymerase beta subunit (rpoB) (primers Fh-rpoB/F and Fh-rpoB/R; Brevik et al. 2011). Both reactions used $1 \mu$ of undiluted, extracted DNA as template and were performed with HotStar Taq (Qiagen) in a $25 \mu$ reaction volume with final concentrations of the following: $1 \times$ Buffer, $5 \times \mathrm{Q}$ Solution, $3 \mathrm{mM} \mathrm{MgCl}_{2}, 0.2 \mathrm{mM}$ dNTPs, $0.1 \mu \mathrm{M}$ for-

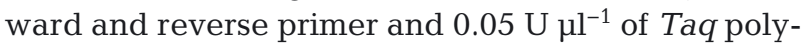
merase. The thermal cycling conditions were $5 \mathrm{~min}$ at $95^{\circ} \mathrm{C} ; 40$ cycles of $30 \mathrm{~s}$ at $95^{\circ} \mathrm{C}, 30 \mathrm{~s}$ at the appropriate annealing temperature $\left(55^{\circ} \mathrm{C}\right.$ for $968 \mathrm{f}$ and $1401 \mathrm{r}$ and $52^{\circ} \mathrm{C}$ for Fh-rpoB/F and Fh-rpoB/R) and $30 \mathrm{~s}$ at $72^{\circ} \mathrm{C}$; followed by a final cycle of $10 \mathrm{~min}$ at $72^{\circ} \mathrm{C}$. PCR products were visualized on $1.5 \%$ agarose gels stained with SYBR Safe (Thermofisher). Five $\mu$ l of each PCR product were purified for sequencing using EXOSap-IT (USB), and sequencing reactions were carried out using Life Technologies Big Dye Terminator v3.1 with $1 \mu$ of purified PCR product as template, according to the manufacturer's standard protocol. Sequencing reactions were then purified using the DyeEX 2.0 Spin Kit (Qiagen) and run on an ABI $3130 x l$ genetic analyser. 


\section{In situ hybridization}

Five $\mu \mathrm{m}$ tissue sections were deparaffinized, and in situ hybridization (ISH) was performed based upon the procedures and probes published by Kamaishi et al. (2010), with minor modifications as follows. The 3 oligonucleotide probes Megai-110r, Megai-230r and Megai-870r (Kamaishi et al. 2010) were purchased with the 3' end digoxigenin label already incorporated (Integrated DNA Technologies). Proteinase K concentration was increased to $10 \mu \mathrm{g} \mathrm{ml} \mathrm{m}^{-1}$. The hybridization solution and probe concentration of each of the 3 probes used in combination was the same as published by Kamaishi et al. (2010); however, the incubation time was shortened to $2 \mathrm{~h}$ at $60^{\circ} \mathrm{C}$ (overnight incubation at $39^{\circ} \mathrm{C}$ was eliminated). The post hybridization washes were the same as published, and similarly, the signal was detected immunologically using anti-digoxigenin-alkaline phosphate Fab fragments (Roche) in conjunction with BCIP/NBT liquid substrate system (Sigma-Aldrich) and counterstained using Bismark Brown Y.

P. yessoensis samples selected for ISH included 10 specimens collected from Baynes Sound during the late fall of 2015 mortality event which displayed a range of macro- and microscopic lesions; 6 specimens collected from a healthy population of scallops in Sutil Channel, BC, (approximately $75 \mathrm{~km}$ north of Baynes Sound) on 7 December 2015 which were not experiencing mortality and had no lesions; as well as 3 archived specimens with similar lesions which were collected from the following locations in $\mathrm{BC}$ : Departure Bay (Nanaimo) in January 1991, Read Island (northeast of Campbell River) in October 1995 and Cypress Bay (north of Tofino) in October 1995.

\section{RESULTS}

\section{Histology}

Histopathology was observed in $44 \%$ of the scallops examined and consisted of varying levels of multifocal and diffuse haemocyte infiltration within the adductor muscle as well as the connective tissue of all organs. The lesions ranged from small irregu- lar patches of diffuse haemocyte infiltration (Fig. 1b) to encapsulated foci containing densely packed necrotic cells (Fig. 1c) with the largest lesions usually occurring in the adductor muscle (Fig. 1a). No causative agents were detected via examination of $H \& E$ stained slides. However, examination of Gram-stained slides revealed the presence of a few small Gramnegative intracellular bacteria inside necrotic cells (presumably haemocytes) within the lesion areas (Fig. 1d). Although the numbers of bacteria were relatively scarce, they were observed consistently in multiple specimens.

\section{In situ hybridization}

All 10 specimens collected from Baynes Sound, BC, during the fall of 2015 displayed intense positive reactions (dark brown/black colouration) showing multiple foci of infection (Fig. 2a,c,d). Serial tissue sections processed for ISH without probes showed no reaction (Fig. 2b). The adductor muscle was the most commonly affected tissue (Fig. 2c), followed by the digestive gland, gonad and heart, and in a few spec-
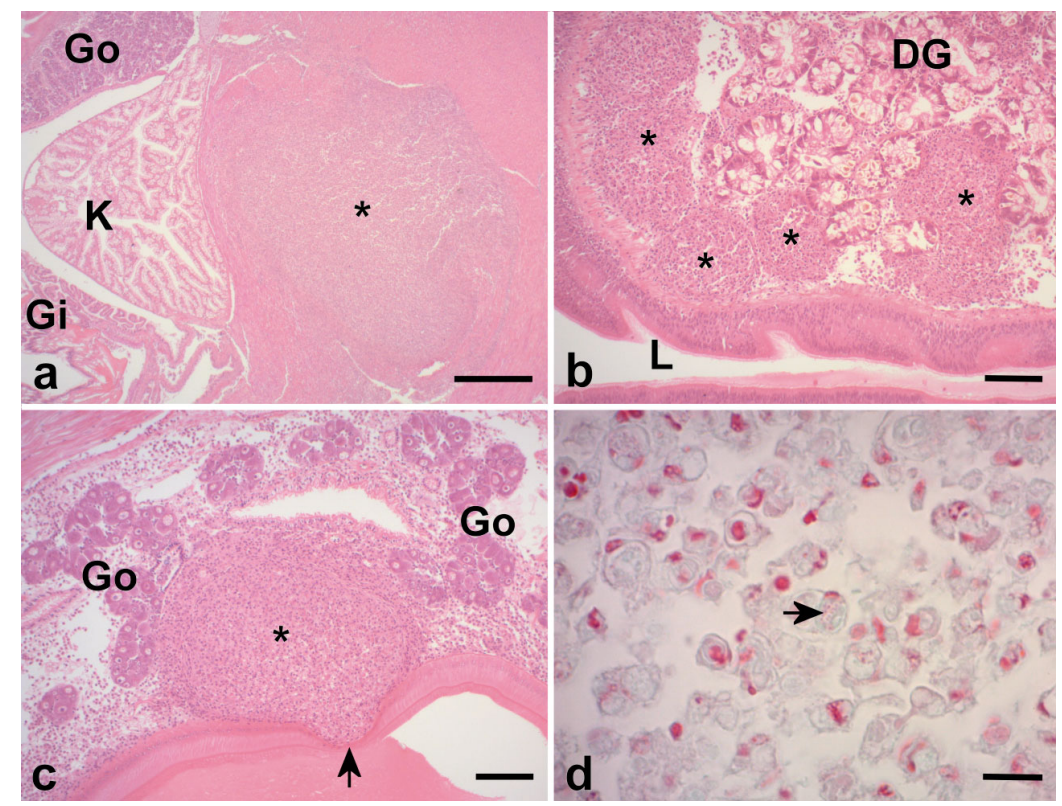

Fig. 1. Histological tissue sections of diseased Patinopecten yessoensis stained with $(\mathrm{a}-\mathrm{c}) \mathrm{H} \& \mathrm{E}$ or (d) Gram stain. (a) Low magnification showing a very large lesion $\left({ }^{*}\right)$ within the adductor muscle and adjacent to the gonad (Go), kidney (K) and gill (Gi). Scale bar $=500 \mu \mathrm{m}$. (b) Irregular multifocal/diffuse patches of haemocyte infiltration ( ${ }^{*}$ ) in the connective tissue of digestive gland (DG) adjacent to the basal membrane of the stomach epithelium and stomach lumen (L). Scale bar $=100 \mu \mathrm{m}$. (c) Focal lesion $\left({ }^{*}\right)$ in the connective tissue of the gonad (Go) on the verge of causing ulceration of the intestinal epithelium (arrow). Scale bar $=100 \mu \mathrm{m}$. (d) High magnification showing tiny Gram-negative bacteria (arrow) inside a necrotic haemocyte within a lesion. Scale bar $=10 \mu \mathrm{m}$ 


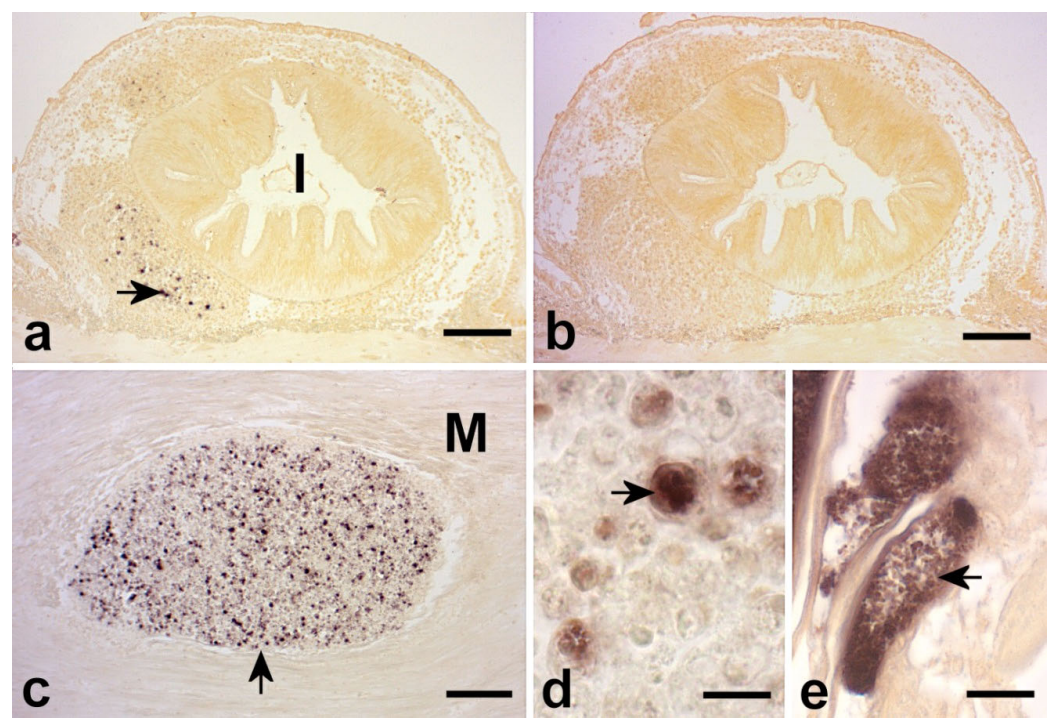

Fig. 2. Histological tissue sections of Patinopecten yessoensis stained using digoxigenin in situ hybridization (ISH). (a) Arrow indicates positive hybridization signal within a lesion adjacent to the intestine (I) stained using probes; (b) serial tissue section of (a) stained without probes showing no reaction. (c) Intense positive hybridization signal (arrow) is limited to the lesion area, while no signal is observed in the surrounding adductor muscle (M). (d) Magnification of (c) showing that although individual bacteria are difficult to discern, intense positive signal was commonly observed in necrotic haemocytes (arrow), which is presumably the result of phagocytosis and the presence of $F$. halioticida DNA. (e) Strong positive ISH reaction (arrow) to a colony of Rickettsialike prokaryotes coincidently observed in the gill epithelium of 'healthy' scallops. Scale bars $=(\mathrm{a}-\mathrm{c}) 100 \mu \mathrm{m},(\mathrm{d}, \mathrm{e}) 10 \mu \mathrm{m}$ currence within membrane vacuoles possibly from a phagosome (Fig. 3b). TEM examination failed to reveal evidence of viral infection or any other aetiological agents.

\section{Sequence analysis}

Sequence fragments from the $16 \mathrm{~s}$ rDNA region of 2 samples (413 bp) and fragments from the $r p o B$ region of 3 samples (925 bp) were respectively identical. Blast results of these fragments were a $100 \%$ match to the reference sequences for Francisella halioticida published by Brevik et al. (2011) (GenBank accession numbers JF290369 and JF290381/JF290374). Sequence diversity in both of these gene regions is represented in this genus, although is much greater in $r p o B$. The most similar rpoB sequence to $F$. halioticida is $F$. cf. novinda (CP002558), which is only $86.6 \%$ identical, while $F$. persica (CP013022) was $99.1 \%$ identical to $F$. halioticida at the 16 s region.

\section{DISCUSSION}

imens, positive reactions were also observed in the mantle and gills, suggesting systemic infection. In addition, the 3 archived specimens from 1991 and 1995 also displayed strong positive ISH reactions as described above.

No lesions were observed in the 6 'healthy' specimens, although 5 of the 6 specimens coincidentally showed strong positive reaction with Rickettsia-like prokaryotes (Fig. 2e), commonly observed organisms within the gills of scallops and many other species of bivalves (Bower 2010).

\section{TEM}

Tissues from 3 individuals were examined, confirming the presence of small coccobacilli in the lesions. The bacteria were relatively scarce, typically occurred within the cytoplasm of necrotic haemoyctes and measured 1 to $1.75 \mu \mathrm{m}$ in diameter. Bacteria were observed with homogenous distribution of chromatin (Fig. 3a) as well as examples showing electron lucent regions (Fig. 3b). In addition, evidence of division via binary fission was observed (Fig. 3a), as well as oc-
Given that Francisella halioticida has a unique sequence at both regions amplified in this study combined with the positive ISH results, it is highly suggestive that $F$. halioticida is the causative agent of the pustules and associated mortalities in Patinopecten yessoensis.

Francisella spp. are pleomorphic intracellular bacteria (Sjöstedt 2005). Although the ultrastructural appearance of the bacteria in this study (Fig. 3) is similar to some specimens of F. tularensis in host cells depicted by Clemens et al. (2009) and Lian (2016), they look different from the electron micrographs presented for F. halioticida by Brevik et al. (2011). Also, the bacteria measurements recorded in this study via TEM fall within the size range of Francisella spp. (Sjöstedt 2005), but they were larger than those reported for $F$. halioticida by Brevik et al. (2011) (1-1.75 $\mu \mathrm{m}$ compared to $0.5-1 \mu \mathrm{m}$, respectively). These discrepancies could be attributed to comparison of bacteria from chronic in situ infections (this study) versus cultured bacteria which were in active growth phase (Brevik et al. 2011). In addition, 


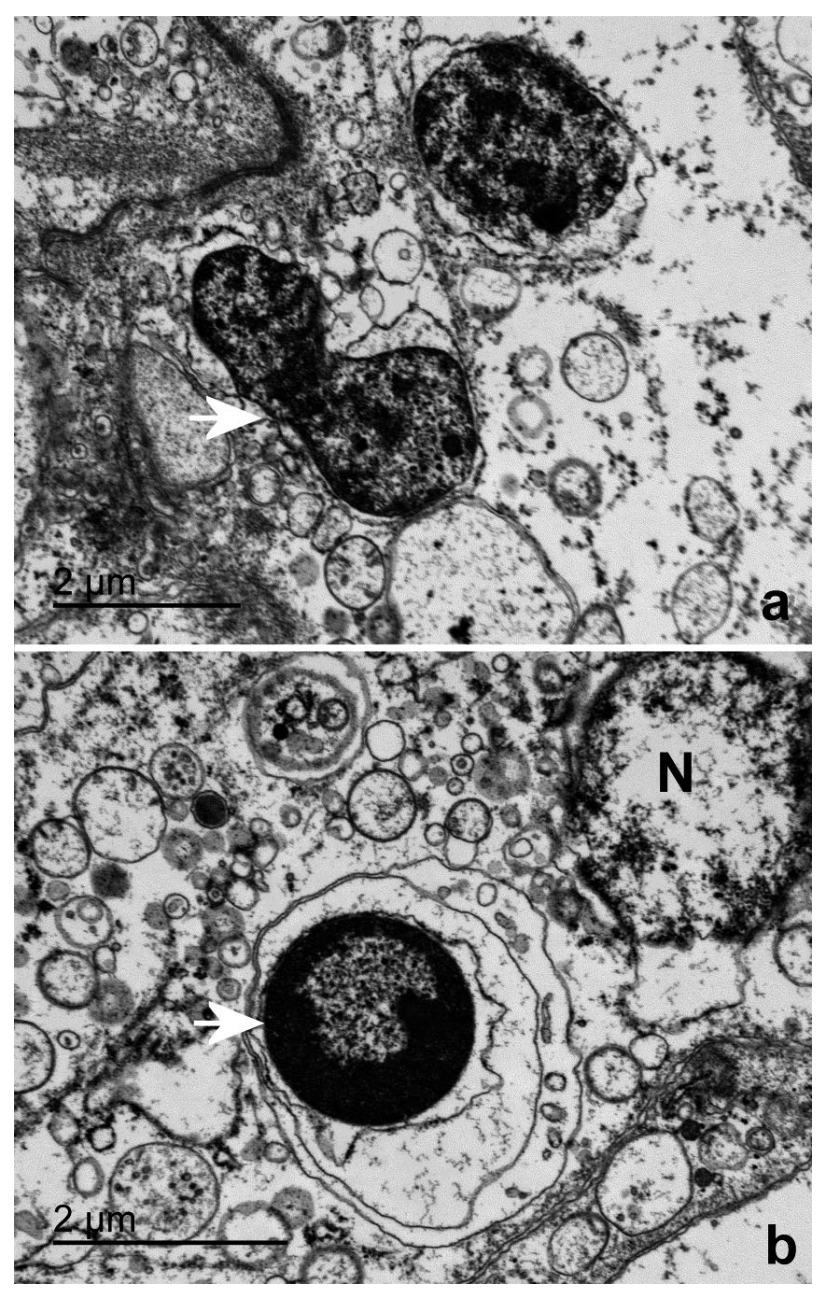

Fig. 3. Transmission electron micrographs showing examples of the bacteria present within lesions in adductor muscle of Patinopecten yessoensis. (a) Two bacteria within the cytoplasm of a necrotic cell showing evenly distributed chromatin, and 1 which appears to be undergoing binary fission (white arrow). (b) Single coccoid bacterium (white arrow) bound by multiple membranes (phagosome) within a necrotic haemocyte adjacent to the host cell nucleus (N). Scale bars $=2 \mu \mathrm{m}$

our TEM observations confirmed the intracellular lifestyle of these bacteria and their ability to reside in membrane-enclosed vacuoles (phagosomes). Bakkemo et al. (2011) indicated that these habits are a common feature of Francisella spp. and may function as a survival and replication niche as well as a method of evading the host immune response.

The strong positive ISH reaction to the bacteria under investigation in this study concurs with those for F. halioticida (Kamaishi et al. 2010). However, an equally strong positive ISH reaction was coincidently observed with Rickettsia-like prokaryotes in the gill epithelium of the 'healthy' population of scallops.
This observation indicates that probes published by Kamaishi et al. (2010) are not specific to F. halioticida. Subsequent to this finding, additional ISH assays were conducted using samples of 2 bacterial pathogens of molluscs (Nocardia crassostreae and 'Candidatus Xenohalitis californiensis') and 2 bacterial pathogens of finfish (Aeromonas salmonicida and Renibacterium salmoninarum), and the probes did not react with any of these bacteria. Regardless, further research needs to be done concerning the specificity of probes published by Kamaishi et al. (2010), especially with respect to other Francisella spp. as well as other types of Gram-negative, intracellular coccobacilli. The positive ISH results observed in the 3 archived specimens suggest that $F$. halioticida was quite likely the aetiological agent responsible for lesions observed in cultured scallops from BC during the late 1980s and 1990s. However, this hypothesis has less certainty given that DNA sequence data are not available for the archived samples and that the probes are now known to be non-specific. In addition, further research needs to be conducted with respect to isolation and culture of $F$. halioticida from Yesso scallops grown in BC, as well as experimental disease challenges.

Acknowledgements. This study was financially supported by Fisheries and Oceans Canada. We thank Eliah Kim for technical support.

\section{LITERATURE CITED}

Bakkemo KR, Mikkelsen H, Bordevik M, Torgersen J and others (2011) Intracellular localisation and innate immune responses following Francisella noatunensis infection of Atlantic cod (Gadus morhua) macrophages. Fish Shellfish Immunol 31:993-1004

Bower SM (2010) Synopsis of infectious diseases and parasites of commercially exploited shellfish. www.dfompo.gc.ca/science/aah-saa/diseases-maladies/index-eng. html (accessed on 23 November 2016)

Bower SM, Meyer GR (1994) Causes of mortalities among cultured Japanese scallops, Patinopecten yessoensis, in British Columbia, Canada. In: Bourne NF, Bunting BL, Townsend LD (eds) Proceedings of the $9^{\text {th }}$ International Pectinid Workshop, Vol 1. Can Tech Rep Fish Aquat Sci 1994:85-94

* Bower SM, Blackbourn J, Meyer GR, Nishimura DJH (1992) Disease of cultured Japanese scallops (Patinopecten yessoensis) in British Columbia, Canada. Aquaculture 107:201-210

* Brevik OJ, Ottem KF, Kamaishi T, Watanabe K, Nylund A (2011) Francisella halioticida sp. nov., a pathogen of farmed giant abalone (Haliotis gigantea) in Japan. J Appl Microbiol 111:1044-1056

Clemens DL, Lee BY, Horwitz MA (2009) Francisella tularensis phagosomal escape does not require acidification of the phagosome. Infect Immun 77:1757-1773 
Eigelsbach H, McGann VG (1984) Gram-negative rods and cocci, Genus Francisella. In: Frieg NR, Holt JG (eds) Bergey's manual of systematic bacteriology, Vol 1. Williams \& Wilkins, Baltimore, MD, p 394-406

Getchell RG, Smolowitz RM, McGladdery SE, Bower SM (2016) Diseases and parasites of scallops. In: Shumway SE, Parsons GJ (eds) Scallops: biology, ecology, aquaculture, and fisheries. Elsevier Science, Oxford, p 425-468

Howard DW, Lewis EJ, Keller BJ, Smith CS (2004) Histological techniques for marine bivalve molluscs and crustaceans. Tech Memo NOS NCCOS 5. NOAA, Oxford, MD

Jones SRM, Smith PA (2014) Sporadic emerging diseases and disorders. In: Woo PTK, Bruno DW (eds) Diseases and disorders of finfish in cage culture. CAB International, Wallingford, p 287-312

Kamaishi T, Miwa S, Goto E, Matsuyama T, Oseko N (2010) Mass mortality of giant abalone Haliotis gigantea caused by a Francisella sp. bacterium. Dis Aquat Org 89: 145-154

Lian TA (2016) Ultrastructural characterization of Fran-

Editorial responsibility: Stephen Feist,

Weymouth, UK cisella tularensis subspecies novicida intracellular life cycle in host macrophages. Study of bacterial adherence, phagosome maturation and phagosomal escape. Thesis, University of Oslo

Nübel U, Engelen B, Felske A, Snaidr J and others (1996) Sequence heterogeneities of genes encoding 16S rRNAs in Paenibacillus polymyxa detected by temperature gradient gel electrophoresis. J Bacteriol 178:5636-5643

Nylund A, Ottem KF, Watanabe K, Karlsbakk K, Krossoy B (2006) Francisella sp. (Family Francisellaceae) causing mortality in Norwegian cod (Gadus morhua) farming. Arch Microbiol 185:383-392

* Oyston PCF (2008) Francisella tularensis: unravelling the secrets of an intracellular pathogen. J Med Microbiol 57: 921-930

Sjöstedt AB (2005) Family III. Francisellaceae fam.nov. In: Brenner DJ, Krieg NR, Staley JT, Garrity GM and others (eds) Bergey's manual@ of systematic bacteriology, Vol 2. The Proteobacteria: Part B, the Gammaproteobacteria. Springer US, Boston, MA, p 199-210

Submitted: January 26, 2017; Accepted: April 3, 2017 Proofs received from author(s): May 18, 2017 